\title{
Public Lessons from Private Laws
}

\author{
Gwen Sinclair
}

A casual glance at a volume of Statutes at Large reveals that the laws are presented in two sections: public laws and private laws. While most documents librarians are familiar with public laws, so named because they have general applicability, private laws may be less familiar. A private bill, according to Hinds' Precedents, is "a bill for the relief of one or several specified persons, corporations, institutions, etc., and is distinguished from a public bill, which relates to public matters and deals with individuals only by classes."

The main reason for the low profile of private laws is that they do not have general applicability; they only apply to a particular individual or defined group, although some private laws have been precedent-setting. However, they are useful for a variety of research topics. This article will explore the most important types of private legislation, discuss the various Congressional committees that have considered private bills, review the legislative process, and provide some examples of private bills to illustrate examples problems that required private legislation in order to be resolved. The information value of reports on private laws and House and Senate records related to private laws will also be explored.

\section{Categories of Private Legislation}

We've all heard the saying, "It takes an act of Congress to ..." accomplish some seemingly simple task. The thousands of private laws considered and passed by Congress are evidence that yes, in many cases, it does require an act of Congress to right wrongs, settle claims, convey title to property, resolve immigration problems, and bring about a wide variety of other actions.

\section{Pensions, Military Honors, Promotions}

Numerous private laws have been passed to grant pensions to former government employees, members of the armed services, and their survivors. A remarkable example is that of a pension awarded to Mary Lord Harrison, widow of President Benjamin Harrison. While pensions had been granted to many presidents' widows, Mrs. Harrison's case was controversial because she became the former president's wife after his term of office had ended and five years before his death in 1901. Nevertheless, the bill was passed over the objection of Senator Walsh, who argued that the $\$ 5,000$ annual pension was excessively generous. ${ }^{2}$

Congress has passed private laws to grant military promotions, decorations, and pensions throughout its history. After the Civil War, many private laws were passed to correct military service records, award pensions to surviving spouses, and even to restore political rights to former rebels. ${ }^{3}$ An unusual case was that of George A. Armes, who was the subject of several private laws introduced to rectify his Army service record. Armes, a second lieutenant, was court-martialed in 1870 based in large part on what was later determined to be unreliable testimony. A private law was introduced that year to grant him an honorable discharge. Under another piece of private legislation, in 1878 he was retrospectively granted the rank of Captain. He was forced to retire at the rank of Major in 1883. Further legislation was introduced in 1901 to retrospectively grant him the rank of Brigadier General under the argument that if he had not been forced to retire in 1883 , he would have continued up the ranks. This bill was not successful, and a later bill introduced in 1914 (also unsuccessful) only would have granted him the rank of Colonel. ${ }^{4}$

It may be surprising to some that Congress has the power to award military honors, since that responsibility would appear to lie within the sole jurisdiction of the executive branch under the president, who is commander in chief of the armed services. Nonetheless, many private laws have been passed to award military honors. In the cases of Merchant Mariners James Thomas Lantz, Jr., David D. Bulkley, and Arthur J. Abshire, Congress passed a law in 1978 awarding them various decorations and awards for their service during World War II. ${ }^{5}$ Evidently, the men had not applied for the medals within the statutory limitations. Congress has also passed laws enabling Americans to receive foreign military honors. This was necessary because acceptance of an honor from a foreign government would 
normally be prohibited under the Emoluments Clause of the US Constitution. ${ }^{6}$

\section{Land Titles and Access}

Private legislation has been used to transfer title from the federal government to private owners, quiet title in cases where the federal government has an ownership interest, or grant access to privately owned parcels through federal land.

An interesting example of a claim made long after the fact involved President George Washington's estate. Washington had purchased parcels of land in Ohio in 1779 under a law that enabled Revolutionary War veterans to obtain military warrants. Washington believed that the warrants had been properly registered with the State of Virginia. However, the warrant and surveys should have been registered with the War Department. Joseph Kerr, a deputy surveyor with the Virginia military district of Ohio, took advantage of this oversight and fraudulently obtained warrants for Washington's parcels. Washington's heirs failed to take advantage of opportunities to remedy the fraud and settle the matter during the nineteenth century. Several private bills were introduced between 1908 and 1919 to authorize payment to the Washington estate's claim for the value of the land. Evidently, none of the bills passed.

Private bills to quiet title have sometimes been needed to resolve cases where documentation is lacking. In one instance, private bills were introduced to quiet title on parcels in the District of Columbia as the result of an investigation into property that was on a federal property inventory but not actually in the possession of the United States. In 1924, Senate Bill 3053 was introduced to quiet title for a parcel, now the site of an office building at 1919 M Street NW, that had been conveyed by the United States to George H. Walters in 1867. However, no deed from the United States to Walters was found, so a law to settle the title was the necessary remedy. ${ }^{8}$

An unusual situation involving government property concerned a faulty US government survey. Private Law 516 of the 75th Congress (52 Stat 1311) enabled the US government to sell a 1,700-acre parcel of land to the Nicolson Seed Company of Utah, since the existing law that would enable such a sale applied only to parcels of 160 acres or less. The private legislation was needed because the alfalfa farmers who had originally purchased the parcel from the State of Utah learned through a resurvey that a dry lakebed that they had improved was in the public domain and was no longer theirs!

In other cases, private legislation conveyed US government property to states or territories, although this has also been accomplished at times through public legislation. Private laws were also used to permit the transfer of land to residents of Indian reservations. ${ }^{10}$ Laws were also passed to provide for ingress and egress through federal property to reach private property, as in the case of Roscoe L. Wood, who was granted an easement through federal property in Cabin John Park (now Cabin John Regional Park), Maryland in 1947.11

\section{Relief of Liability of Government Employees}

Private legislation has sometimes been needed to abrogate the liability of government employees for the misdeeds of other employees or to absolve them of responsibility for thefts. In particular, postmasters were held responsible for the theft of funds by postal employees. In one instance, Honolulu Postmaster D. H. MacAdam was held liable for funds embezzled by employee William C. Peterson. The Postmaster General felt that MacAdam was liable because of his lack of oversight over Peterson. However, the House report on the bill identified an extenuating circumstance that would justify reimbursing MacAdam for the embezzled funds charged against him. The circumstance? Employees in the post office were "Chinese, Japanese, Hawaiians, and Portuguese, many of whom understood and spoke the English language to a very limited extent." It was argued that Peterson took advantage of the employees' lack of facility with English to embezzle funds from money orders and other remittances. Thus, MacAdam was relieved of responsibility for the theft. ${ }^{12}$

Loss of funds due to robbery was also chargeable to the postmaster, resulting in private laws such as one to relieve Martin A. King, postmaster in Clarks Summit, Pennsylvania, whose post office was robbed of $\$ 410.53$ in 1934 . The private law releasing him from liability for this loss was passed in $1948 .^{13}$

\section{Claims against the US Government for Damages}

Another important category of private legislation has been bills introduced to authorize the settlement of claims against the government. Claims may be made for pension benefits, damage caused by members of the armed services, or to right other wrongs caused by employees or agents of the US government. Claims committees were established early on in both the House of Representatives and Senate to review claims and to make recommendations on private legislation on claims. Records of the various claims committees in the House are quite voluminous. Table 1 lists the main House committees that have existed to consider claims. ${ }^{14}$

In contrast to the House's ten claims committees, only a few Senate committees exclusively heard claims because many claims were referred to a variety of other committees such as 
Table 1. Claims Committees in the House of Representatives

\begin{tabular}{|l|l|l|}
\hline Name of Committee & Dates of Operation & Types of Claims Heard \\
\hline Committee on Claims & $1794-1946$ & All types \\
\hline $\begin{array}{l}\text { Committee on Pensions and Revolutionary } \\
\text { War Claims }\end{array}$ & $1813-25$ & Claims relating to the Revolutionary War \\
\hline Committee on Military Pensions & $1825-11$ & Pensions for military service; invalid pensions \\
\hline Committee on Invalid Pensions & $1831-1946$ & Pensions for disabled veterans \\
\hline Committee on Revolutionary Pensions & $1831-80$ & Military pensions relating to the Revolutionary War \\
\hline Committee on Pensions & $1880-1946$ & Pensions of all wars other than the Civil War \\
\hline Committee on Revolutionary Claims & $1825-73$ & Claims originating in the Revolutionary War \\
\hline Committee on War Claims & $1873-1946$ & Claims arising from any war, mostly Indian war and Civil War claims \\
\hline Committee on Private Land Claims & $1816-1911$ & Private land claims \\
\hline Committee on the Judiciary & $1813-1968$ & Claims not falling under the specialized claims committees \\
\hline
\end{tabular}

the Committee on the Judiciary or the Committee on Military Affairs based on subject matter. Table 2 lists the Senate committees that exclusively considered claims. ${ }^{15}$

The Court of Claims was created in 1855 . Prior to its establishment, claimants had to apply to the Treasury Department for relief and, if a claim was not settled, the claimants could petition Congress for relief. ${ }^{16}$ Following the Civil War, hundreds of private laws on claims were passed. While most laws benefited a single individual, some, like 23 Stat 552, An Act for the Allowance of Certain Claims Reported by the Accounting Officers of the United States Treasury Department, and for Other Purposes, awarded claims to hundreds of persons.

The Bowman Act of 1883 (22 Stat 485) and the Tucker Act of 1887 (24 Stat 505) were attempts to increase the powers of the Court of Claims and thereby divert to it some of the volume of claims, but these measures were only partly successful. The Court of Claims rendered decisions on the claims referred to it and reported them back to the Committee on Claims. These reports can be found in the US Congressional Serial Set. ${ }^{17}$ They are of interest to researchers because they describe in detail the losses claimed by individuals as well as the Court of Claims' rationale for upholding or denying each claim.

Frequently, decades elapsed between the incident for which a claim was made and the time a report was issued by the Court of Claims. For example, a report on the claims of the heirs and assigns of the owners and insurers of the ship Pattern, which had been seized by the French privateer Trompeuse in 1796, was referred to the Committee on Claims on December 10, 1915. ${ }^{18}$ Later, the Committee on Claims passed general legislation permitting the Court of Claims to dispose of all of the French spoliation claims (claims by Americans against the French government for illegal seizures of property). ${ }^{19}$

Many, many private laws have been passed to authorize payment to individuals and businesses for losses sustained as a result of the actions of government employees. A few private laws were passed to enable the owners of vessels damaged in collisions with US government-owned vessels to sue for damages in the US District Court acting as an admiralty court. Thus, Private Law 161 of 1925, passed in the 68th Congress, second session, authorized the owners of the Ceylon Maru, a Japanese vessel damaged in a collision near France with the American steamship Jeannette Skinner, which was being operated by the War Department, to bring suit against the United States. ${ }^{20}$ Without such legislation, the District Court did not have jurisdiction to hear an admiralty case.

Humans were not the only subject of claims. Trixie, a Tennessee walking horse owned by J. Rutledge Alford of Tallahassee, Florida, died from drinking water contaminated by seepage from a laundry at a nearby federal prison. Congress approved the payment of $\$ 450$ in settlement of Alford's claim. ${ }^{21}$

\section{Other Claims}

Private legislation is sometimes the only mechanism available to remedy a clear injustice. The First Baptist Church of Paducah, Kentucky found a sympathetic ear in Congress in its quest for justice. The Senate Committee on the Judiciary recommended in 1978 that the church be paid \$207,740 in settlement of claims against the US for its failure to follow through on a planned condemnation of church property, first announced in 1964 . The amount was reduced by the House to $\$ 171,990$, still far more than the General Services Administration's offer of $\$ 47,725$. $^{22}$

Less commonly, private legislation was required to reimburse individuals for fines or fees for which they were deemed not liable, as the case of Elwood L. Keeler illustrates. He was convicted in 1941 of attempting to sell industrial diamonds to Japan in violation of the law, sentenced to prison, and fined $\$ 5,000$. In June 1945, President Truman pardoned him, but 
Table 2. Claims Committees in the Senate

\begin{tabular}{|l|l|l|}
\hline Name of Committee & Dates of Operation & Types of Claims Heard \\
\hline Committee on Claims & $1816-1946$ & All types \\
\hline Committee on Private Land Claims & $1826-1921$ & Private land claims \\
\hline Committee on Revolutionary Claims & $1832-1921$ & Pensions and other Revolutionary War-related claims \\
\hline
\end{tabular}

because he had not appealed his sentence, he was not entitled to a refund of the fine, thus necessitating private legislation to enable his reimbursement. ${ }^{23}$

\section{Immigration Cases}

If you've seen the film American Hustle, you've encountered one type of private legislation related to immigration. In the film, which was loosely based on true events in the Abscam scandal, members of Congress accept bribes offered by FBI operatives in exchange for sponsoring private legislation to enable individuals from the Middle East to become US citizens. Although no private laws were actually introduced into Congress by the corrupt officials nabbed in the Abscam sting operation, thousands of private bills have been introduced to resolve a variety of immigration-related cases. ${ }^{24}$ Private bills on immigration can be divided into four categories: bills to permit the entry of adopted alien children, bills to permit entry by statutorily excluded aliens such as people with criminal histories or mental or physical disabilities, bills to relax citizenship requirements, and bills to grant permanent residence to aliens. ${ }^{25}$

Following World War II, thousands of private laws were introduced in Congress to deal with myriad immigration problems. A common scenario involved soldiers or sailors who became engaged to or married women abroad who were not eligible to immigrate to the United States because of racial exclusion laws, in the case of Japanese and Korean women, or because national origin quotas had been filled. In such cases, private laws were introduced to enable these individuals to be admitted to the US Many of these bills were never acted upon, but in thousands of cases, private legislation enabled the wives and children of service members to immigrate.

Another class of individual requiring private relief included members of the armed services who were not US citizens, some of whom were not in the US legally. A number of private laws were passed to grant citizenship to such individuals (e.g., An act to provide for the naturalization of certain United States Army personnel-Yugoslav fliers, 61 Stat 1004).

Private legislation has been used to allow the adopted children of US citizens to enter the US, as in the case of Natividad Casing and Myrna Casing, two Filipino women who, along with their younger siblings, were adopted by Winston A. and Pacita Ashford. The legislation classified the women as children under the Immigration and Nationality Act (i.e., treated them as if they were under the age of fourteen) so that they could be admitted. ${ }^{26}$

Immigrants who had not entered the United States legally were sometimes granted legal status through private legislation. Frequently, individuals who had overstayed student or tourist visas or who had sneaked in were beneficiaries of private legislation. An unusual case was that of teenager Joseph Ochrimowski, who entered New York from Poland as a stowaway in $1946 . \mathrm{He}$ had escaped from a German slave labor camp near Essen and had been adopted as a sort of mascot by the 84 th Infantry Division of the 334th Infantry, which had transported him to the United States in hopes that he would be granted admission. A private law, passed over the objection of the Attorney General, stipulated that he should be treated as if he had been lawfully admitted even though it was not possible to admit him administratively due to the overwhelming demand for slots within the Polish immigration quota. ${ }^{27}$

Private laws also benefited individuals who were not eligible for admission to the United States. Reasons for ineligibility included having voting in a foreign election or having been convicted of a crime. In several cases, women who had lost their citizenship by marrying an alien who was ineligible for US citizenship and who lived abroad petitioned members of Congress to sponsor private legislation to enable them to return to the United States. ${ }^{28}$

Finally, private legislation has been introduced to allow immigration by individuals with sought-after skills. One of the more eyebrow-raising examples was the case of Basque sheepherders who were permitted to enter the United States under eighty separate private laws introduced between 1949 and $1957^{29}$

\section{Procedures}

Procedures and rules for handling private legislation have changed many times over the years. Currently, when members of Congress are contacted by constituents or advocacy groups about situations that could potentially be remedied through a private bill, the member takes steps to see if there are administrative remedies that could resolve the matter. If a private bill is determined to be the only possible remedy, the matter is referred to the relevant subcommittee such as the Subcommittee on 


\section{Private Laws as a Percent of Total House Bills}

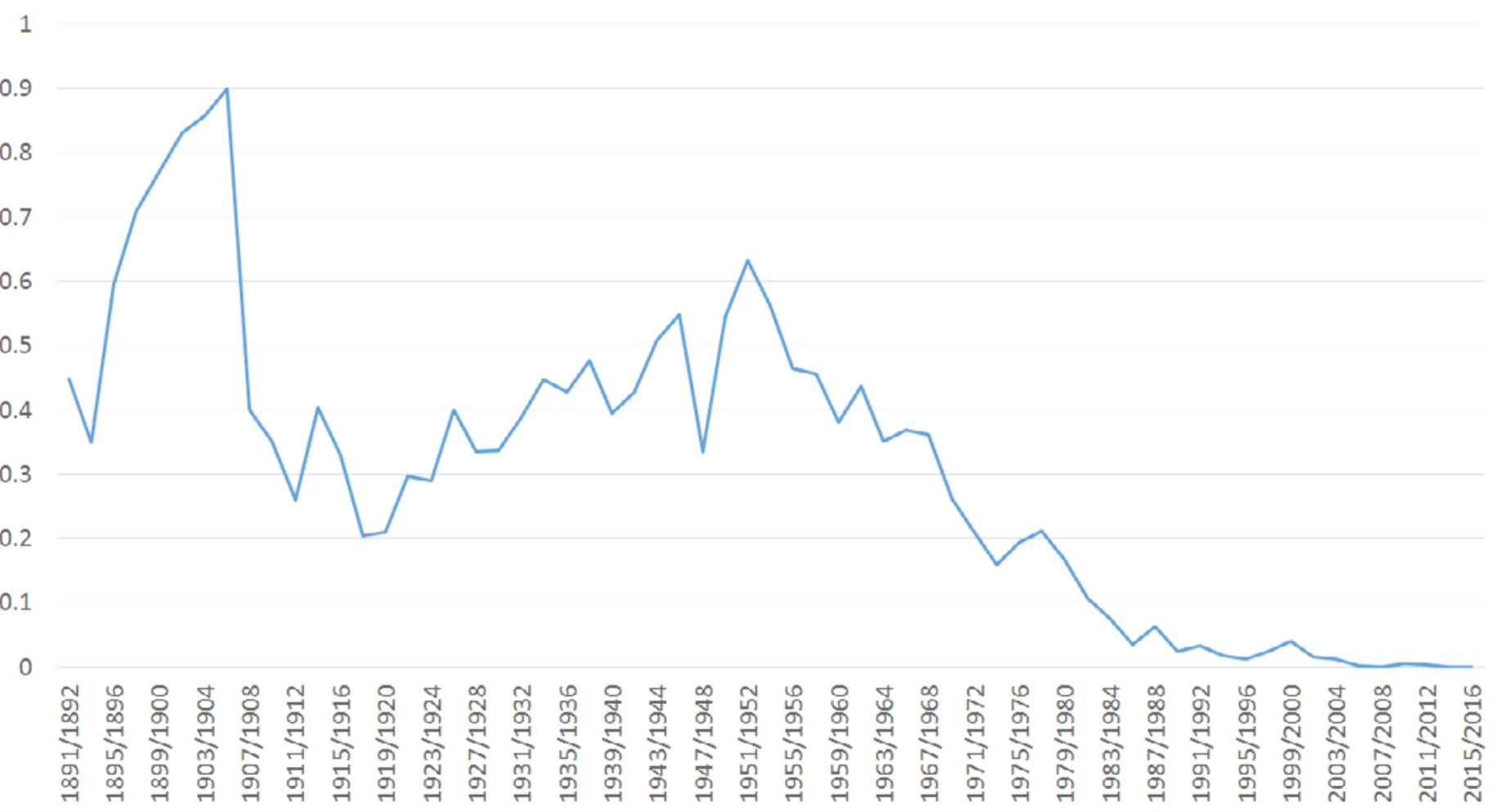

Figure 1. Private Laws as a Percent of Total House Bills. Compiled from “Comparative Statement, Work of the Fifty-Second to the One Hundred Fourteenth Congress, Inclusive, House of Representatives," in Calendars of the United States House of Representatives and History of Legislation, 114th Cong., 1st sess., 2016, 19-52, bit.ly/2s2PLjy.

Immigration for further review. Legislation may be drafted by the member's office or by the Office of Legislative Counsel in the House or Senate. The member typically provides a letter outlining the facts of the matter to the relevant subcommittee. ${ }^{30}$

The majority of private bills are introduced in the House. In contrast to public bills, a companion bill is not usually introduced in the other chamber. Most bills are referred to the Committee on the Judiciary of either the House or the Senate. In the House, most private bills are considered on the Private Calendar, while in the Senate, private bills are handled like any other piece of legislation. ${ }^{31}$

If a bill has not been excluded after being reviewed by a subcommittee, reports from relevant executive branch agencies may be requested, usually by the chair of the House or Senate Judiciary Committee. The subcommittee reviews the information provided by the executive branch agency, then if it decides to take favorable action on the bill, it is submitted to the full Judiciary Committee. If the full committee votes favorably on the bill, it issues a report and is scheduled for consideration by the full chamber. It is uncommon for a private bill to be amended once it has been reported out by the Judiciary Committee. $^{32}$
Private bills, once passed by Congress, appeared to have enjoyed great success when submitted to the president, for there are few recorded vetoes of private legislation. Presidential vetoes of private legislation have only rarely been subject to override measures. ${ }^{33}$

\section{Publications and Records Related to Private Legislation}

Bill files in the records of the House and Senate at the National Archives contain original petitions and memorials with supporting documents. They are of interest not only to genealogical researchers but also to researchers interested in a particular type of claim, such as claims denied by the Southern Claims Commission, which heard the claims of Southerners who remained loyal to the North during the Civil War. ${ }^{34}$

House and Senate reports on private bills may include the full text of the bill or excerpts from legislation, letters from the federal agencies involved, letters of support for the claimant, and even transcripts of field hearings and testimony. Congressional papers of representatives and senators contain case files related to private laws they introduced. 


\section{Recent Developments}

Congress has drastically reduced the volume of private legislation by leaving it up to the Executive Branch to resolve most immigration matters, claims, and property transfers. Figure 1 (Private laws as a percent of total House bills) shows the decline in House bills on private legislation as a percent of all laws passed from peak periods around the turn of the twentieth century and following World War II. Most private laws originate in the House, so viewing House bills on private legislation as a percent of the total legislation considered in the House gives a good picture of how their prevalence has fluctuated.

In the past few Congresses, only a handful of private bills have been introduced, mostly for immigration cases, but they almost never become law. ${ }^{35}$ One persistent case is that of Ibrahim Parlak, a Kurdish native of Turkey who was granted asylum and entered the United States in 1991 but was later subject to deportation proceedings. Michigan Rep. Fred Upton has introduced private legislation in Congress each year since 2005 to grant Parlak permanent residency, but as of this writing the legislation has not advanced. ${ }^{36}$

Notwithstanding Ibrahim Parlak, private legislation is mostly a thing of the past, primarily of interest to genealogy researchers and historians. Congress has passed rules to greatly restrict the use of private legislation, and most of the situations that could formerly be remedied by Congress are now under the exclusive jurisdiction of the executive branch. ${ }^{37}$

\section{Conclusion}

This discussion will conclude with a word about the information value of reports and documents related to private legislation. While some patrons may request documents related to a particular private law that concerns their own family history, reports on private legislation also reflect various social movements, historical events, and legal trends. For example, knowing that Congress considered many private bills making claims for injuries due to accidents caused by Civilian Conservation Corps (CCC) vehicles in the 1930s might suggest to a researcher that a number of the CCC drivers may have been inexperienced or unskilled, or the roads they used were dangerous. At times, there has been a clear causal relationship between the volume of private laws introduced and changes in statutory law. As noted above, private legislation on claims resulted in several acts that changed how claims were handled. Maguire has documented many instances where Congress has amended public laws related to immigration because the abundance of private laws have exposed flaws in existing statutes. ${ }^{38}$
The subject matter of private legislation is also a reflection of historical events and trends. Following the Civil War, thousands of claims for damage caused by troops were made and later became the subject of private legislation. In addition, private laws awarded thousands of pensions to Civil War veterans and their survivors well into the twentieth century. In the early twentieth century, immigration bills increased in response to restrictive immigration laws, and after World War II, claims and immigration cases formed the bulk of private bills. This brief article cannot begin to detail the astonishing range of cases brought before Congress for private relief. To truly get a sense of the human dramas behind private legislation requires a plunge into the Statutes at Large and U.S. Congressional Serial Set. Careful, though-you may never want to come out!

Gwen Sinclair (gsinclai@hawaii.edu), Head of Government Documents \& Maps at the University of Hawai'i at Mānoa Library.

\section{References}

1. "Private and District of Columbia Business," 4 Hinds' Precedents 238, 262.

2. Senate Committee on Pensions, Mary Lord Harrison, 75th Cong., 3rd sess., 1938, S. Rept. 1331.

3. Matthew Mantel, "Private Bills and Private Laws," Law Library Journal 99, no. 1 (2007): 90.

4. House Committee on Military Affairs, Maj. George A. Armes, United States Army, Retired, 62nd Cong., 2nd sess., 1912, H. Rept. 496.

5. An Act for the Relief of James Thomas Lantz, Jr., David D. Bulkley, and Arthur J. Abshire, 92 Stat 3812.

6. Mantel, "Private Bills and Private Laws," 90, note 22.

7. House Committee on Private Land Claims, Estate of Gen. George Washington, 61st Cong., 3rd sess., 1911, H. Rept. 2179.

8. Senate Committee on the District of Columbia, To Quiet Title to Original Lot 4, in the District of Columbia, 68th Cong., 1st sess., 1924, S. Rept. 590.

9. House Committee on the Public Lands, Relief of Nicolson Seed Farms, a Utah Corporation, 75th Cong., 3rd sess., 1938, H. Rept. 1806.

10. Senate Committee on Public Lands, Authorizing the Secretary of the Interior to Issue a Patent in Fee to Becker Little Light, 80th Cong., 1st sess., 1947, S. Rept. 541. 
11. Senate Committee on Public Lands, Authorizing the Secretary of the Interior to Grant a Private Right-of-Way to Roscoe L. Wood, 80th Cong., 1st sess., 1947, S. Rept. 184.

12. House Committee on Claims, D. H. MacAdam, 68th Cong., 1st sess., 1924, H. Rept. 119.

13. House Committee on the Judiciary, Martin A. King, 80th Cong., 1st sess., 1947, H. Rept. 1188; An Act for the Relief of Martin A. King, 62 Stat 1338.

14. Charles E. Schamel et al., "Records of the Claims Committees," in Guide to the Records of the United States House of Representatives at the National Archives, 1789-1989: Bicentennial Edition, 75-91 (Washington, DC: National Archives and Records Administration, 1989).

15. Robert W. Coren et al., Guide to the Records of the United States Senate at the National Archives 1789-1989, Bicentennial Edition (Washington, DC: United States Congress, 1987).

16. Schamel et al., "Records of the Claims Committees," 76.

17. Ibid.

18. House Committee on Claims, Ship "Pattern": Letter from the Chief Clerk of Court of Claims, Transmitting Certified Copy of the Findings of Fact and Conclusions of Law in the French Spoliation Claim Relating to the Vessel Ship "Pattern" in the Case of E. K. Hubbard Administrator of Jacob Sebor et al., vs. the United States, 64th Cong., 1st sess., 1915, H. Doc. 145.

19. Schamel et al., "Records of the Claims Committees," 78-79.

20. House Committee on Claims, Owners of the Steamship "Ceylon Maru," 68th Cong., 2nd sess., 1925, H. Rept. 1137.

21. An Act for the Relief of J. Rutledge Alford, 61 Stat 1008; House Committee on the Judiciary, J. Rutledge Alford, 80th Cong., 1st sess., 1947, H. Rept. 772.

22. House Committee on the Judiciary, First Baptist Church of Paducah, Ky., 95th Cong., 2nd sess., 1978, H. Rept. 1035.

23. House Committee on the Judiciary, Elwood L. Keeler, 80th Cong., 1st sess., 1947, H. Rept. 261.
24. Joe Morehead, "Private Bills and Private Laws: a Guide to the Legislative Process," Serials Librarian 9, no. 3 (1985): 115.

25. "Private Bills in Congress," Harvard Law Review 79, no. 8 (1966): 1698-1701.

26. House Committee on the Judiciary, Natividad Casing and Myrna Casing, 95th Cong., 1st sess., 1977, H. Rept. 174.

27. Senate Committee on the Judiciary, Joseph Ochrimowski, 80th Cong., 1st sess., 1947, S. Rept. 1856.

28. Walter H. Maloney, Jr., "Involuntary Loss of American Citizenship," Saint Louis University Law Journal 3, no. 2 (1954): 168-74.

29. Bernadette Maguire, Immigration: Public Legislation and Private Bills (Lanham, MD: University Press of America, 1997), 94.

30. Ibid., chapter 3.

31. Christopher M. Davis, Procedural Analysis of Private Laws Enacted: 1986-2013 (Washington, DC: Congressional Research Service, 2013), 5, http://www.hsdl .org/?view\&did=734624.

32. Richard S. Beth, Private Bills: Procedure in the House (Washington, DC: Congressional Research Service, 2004), bit.ly/2uGtBDv.

33. Maguire, Immigration, 48; Senate, Presidential Vetoes: List of Bills Vetoed and Action Taken Thereon by the Senate and House of Representatives, First Congress through the Eighty-Sixth Congress, 1789-1961 (New York: Greenwood Press, 1968).

34. Schamel et al., "Records of the Claims Committees," 87.

35. Davis, Procedural Analysis of Private Laws Enacted: 1986 2013, 2.

36. Fred Upton, "Ibrahim Parlak," accessed June 14, 2017, http://upton.house.gov/ibrahimparlak/.

37. Jennifer E. Manning, Congressional Statistics: Bills Introduced and Laws Enacted, 1947-2004 (Washington, DC: Congressional Research Service, 2005), 2, bit.ly /2h7bDH4.

38. Maguire, Immigration, 69-198. 